\title{
高齢者向け住宅への住み替えにおける物品の希望持参量に関する研究 QUANTITY OF PERSONAL BELONGINGS PREFERRED BY SOON-TO-BE RESIDENTS OF DWELLING UNITS IN SERVICED HOUSING FOR THE ELDERLY
}

\author{
山田雅 之*，山口健太郎**，高田光雄*** \\ Masayuki YAMADA, Kentaro YAMAGUCHI and Mitsuo TAKADA
}

\begin{abstract}
The purpose of this study was to clarify the quantity of personal belongings that soon-to-be residents of serviced housing for the elderly wished to bring with them. The following points were clarified. (1) On average, they wished to bring 1.8 platters, 3.9 small plates, 1.5 bowls, 3.6 small bowls and 3.2 rice bowls. Concerning cookware, they expressed a desire to bring one of every type of item that they owned. In the case of electrical appliances used for cooking, they wished to bring all the items that they possessed to the new dwelling. (2) They expressed a preference for a table for two people, together with chairs, for situations when they received visitors. (3) They wished to bring the bed that they currently possessed. They did not intend to bring a sofa, but instead a low table and a "kotatsu" with cushions. (4) For each type of clothing item, they intended to reduce the number sharply when moving into their new dwelling. Instead of bringing a large chest of drawers, they wished to bring an average of 2.7 storage cases. (5) They intended to choose a small number from the many books, photograph albums and accessories that were in their existing dwelling.
\end{abstract}

Keywords : Serviced housings for the elderly, Relocation, Personal belongins, Self-supported elderly, Dwelling unit 高齢者向け住宅, 住多替え, 物品, 自立高齢者, 住戸

1. はじめに

\section{1-1. 研究背景}

日本では少子高齢化の進行により、高齢者世帯が増加していく注1)。 高齢者世帯は持ち家を所有している人が多く注2)、現時点においては 自宅での継続居住を求めている人が多い注3)。だが、子供の独立や家 の老朽化を契機に利便性や安心・安全を求め、コンパクトな分譲マ ンションや賃貸住宅等への住み替えを希望する人も増加している注4) 特に 70 歳代以上では、サービスが付帯した高齢者向けの賃貸住宅が 有力な住替え先として挙がっている。2011 年に制度化されたサービ ス付き高齢者向け住宅 (以下、少高住と略す) 注5) は、高齢者の入居 を拒まない賃貸住宅として、要介護になる以前に転居を行う早めの住 み替えの場や、低所得者へのセーフティネットとして、または、特別 養護老人ホームなどの要介護高齢者向けの施設の代替施設として位置 付けられている。2014 年 3 月時点におけるサ高住の供給数は約 14 万 戸であり、2020 年までに 60 万戸の供給が予定されている。このよう に持ち家や施設とは異なるサービスのついた高齢者向けの賃貸住宅の 供給が進められている。

一方で、高齢期における転居（環境移行）は、高齢者の心身機能に 多大な負担を与える。環境への適応能力が低い高齢者に対しては、環
境移行による負荷を最小限にとどめることが重要であり、移行前後の 環境の落差を最小限に止めることが求められる。特に、生活スタイル や居住環境の継続が求められるが、住多替えに際しては住戸面積が縮 小される傾向注 6) にあり、自宅内に所有していた物品注7) を廃棄せざ るをえない場合が多くなる。また、高齢者はその他の年齢の人と比心゙ て家具などの長期耐久財に対する購買意欲が低く、一度、廃棄してし まうと新たに購入することは少なく、最低限のしつらえになりやすい と考えられる。

この物品には「記号」として働く「付加価值」（自己提示的価值、 関倸性の象徵的価值、情緒的価值）が備わっており、大切な物品は自 己アイデンティティを確認したり、示したりするのに役立つとされて いる ${ }^{8)}$ 。さらに居室内の物品はそれらと関わる環境行動を誘発する ${ }^{9)}$ 。 人と物品の間には相互の浸透関係があり、平常時においては両者が安 定した居住環境システムを構築している。そのため環境移行と、それ に伴う物品の堮失は、安定的な居住環境システムの崩壊にもつながる。 物品の喪失には(1)転居等による本人が意図した処分、廃棄を意味する 自発的喪失と、(2)穷盗、被災等による本人が意図せざる㶾失を意味す る非自発的喪失がある ${ }^{8)}$ 。高齢者向け住宅一の転居に伴う喪失は、自 発的喪失だけではなく、転居せざるをえなくなってしまった要因（例
$*$ 京都大学大学院工学研究科 博士後期課程 $\cdot$ 修士 $($ 工学 $)$

** 近畿大学建築学部 准教授・博士 (工学)

*** 京都大学大学院工学研究科 教授・博士 (工学)
Graduate Student, Graduate School of Engineering, KYOTO Univ., M. Eng.

Assoc. Prof., Faculty of Architecture, KINKI Univ., Dr. Eng.

Prof., Graduate School of Engineering, KYOTO Univ., Dr. Eng. 
えば身体機能の低下）を伴うことから非自発的喪失の意味合いを含 む。

このような高齢期における環境移行と物品の関係性を捉えた研究 として、高齢者向け住宅では外山 ${ }^{10)}$ 、大原 ${ }^{11)}$ らの研究が、介護施設 では古賀ら ${ }^{9)}$ 、橘ら ${ }^{12)}$ の研究がある。外山や大原は高齢者向け住宅 への転居に際して前住居で使用していたモノの持参が新しい環境へ の適応を助けることを指摘し、古賀らや橘らは物品の継続という観 点から特別養護老人ホーム（以下、特養）における個室化の有効性 を明らかにしている。このように従前住戸において使用してきた物 品を新しい環境に持ち込むことの重要性は示されている。また、物 品の量に着目した研究として古賀ら ${ }^{13)}$ 、小滝ら ${ }^{14)}$ の研究がある。古 賀らは特養の入居者の居室内の物品を行為対象と観賞対象に区別し、 各対象の物品数とAD L の関係から、低A D L 群では身体状況の低 下が居室内の物品量の減少につながりやすいことを明らかにしてい る。小滝らは特養 20 施設に対するヒアリング調查と内 5 施設の入居 者に対する訪問調查を実施している。その結果、私物総量と高齢者 の諸属性との相関については歩行能力にのみ有意差が見られること を明らかにし、特養の収納計画は画一的なものではなく、歩行能力 に対応した細心の計画が望まれるとしている。このように、要介護 高齢者が生活寸る介護施設における個室の物品量についての研究は なされているが自立や高A D L の高齢者注 8$)$ が生活する高齢者向け住 宅における物品量についての研究は行われていない。

\section{1-2. 本研究における高齢者向け住宅の位置づけ}

少高住には前述の通り(1)早めの住み替えの場、(2)住宅セーフティ ネット、(3)介護施設の代替機能という3つの役割がある。サ高住は 原則 $25 \mathrm{~m}^{2}$ 以上の住戸面積を持ち、各住戸には台所、水洗便所、収納

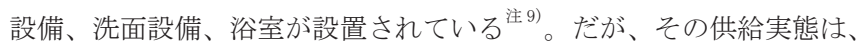
$25 \mathrm{~m}^{2}$ 未満の住戸が全体の $73 \%$ 、住戸内に全ての設備が備わった住戸 ${ }^{\text {注 }}{ }^{10)}$ は $24 \%$ となり ${ }^{15)}$ 、介護施設の代替機能として建設されている場 合が多い。要介護高齢者向けの施設が不足している現状においては、 要介護高齢者向けのサ高住が多くなっているが、環境移行による負 荷を軽減するためには適応能力が高い要介護期以前に転居すること が望ましく、また、前述の通り今後は早めの住み替えを希望する人 も多くなると想定される。そこで、本研究においては高齢者向け住 宅を要介護になる前の高齢者も含めた人を入居対象とし、住戸内で 自立した生活が可能な住宅として位置付ける。

また、文献 17 による曹住における収納設備の設置割合は $96.7 \%{ }^{\text {注 }}{ }^{11)}$ となり、高い值を示寸ものの収納設備についての面積規定 はなく物品量や種類に即した機能を有しているかについては十分に 検討されていない。

以上の背景から高齢者向け住宅には、生活や記憶の継続と、自立 期から要介護期に即した生活という両面が求められている。これら の要素は、いずれも物品を媒体として営まれることが多いことから、 住戸計画に際しては物品の配置が重要となるが、自立高齢者が希望 する物品量やその種類については明らかになっていない。

\section{$1-3$. 研究目的}

そこで本研究では、要介護期になる前の自立期から入居できる高齢 者向け住宅を設計する際の、特に住戸計画を中心とした基礎的資料を 得るために、生活行為の視点から高齢者向け住宅への住み替えを想 定した際に持込みを希望する家具・家電製品・モノ・衣服の持参量注
12) について明らかにするとともに、現在の住まいにおける保有量と の比較から個々の物品の重要性について検証する。

\section{2. 調査概要}

\section{2-1．調査方法の概要（表 1，表 2，表 3）}

調查方法は、高齢者向け住宅への入居を希望する高齢者へのアン ケート調査である。調查概要は表 1 、アンケート回答者の属性は表 2 の通りである。調查対象は、高齢者向け住宅の情報提供や見学会企 画などのサービスを提供する紹介業者 $\mathrm{K}$ （大阪、東京の 2 拠点）の 来訪者と、高齢者向け住宅運営会社 F が主催した見学会の参加者お よび資料請求者である。紹介業者 $\mathrm{K}$ の来訪者および住宅運営会社 $\mathrm{F}$ の見学会の参加者に対しては、アンケート調查についての口頭説明 を行った上でアンケート用紙を手渡し、後日、郵送にて回収した。 紹介業者 $\mathrm{F}$ の資料請求者についてはアンケート用紙を送付し、後日、 郵送にて回収した ${ }^{13)}$ 。アンケート用紙の配布数は 200 部、回収数 は 48 部であり回収率は $24 \%$ であった。

アンケート調査に際しては以下の 5 点を前提条件として提示した。 (1)単身での生活、(2)転居後に自宅は処分すること、(3)住み替え先の 高齢者向け住宅の住戸面積を想定しないこと、(4)住み替え先の高齢 者向け住宅には見守り相談などの生活支援サービスの提供はあるが 介護サービスの提供はないこと、(5)食堂は併設されているが朝昼な どの軽食は基本的に自室で作ること注14) である。

調査内容は、現在の家具・家電製品・モノ・衣服の保有量と、高 齢者向け住宅への入居を想定した際に持ち込みを希望する家具・家 電製品・モノ・衣服の持参量である。調査シートには、表 3 のよう に家具・家電製品・モノの名称をイラストと合わせて表記し、その 下に個数を記入してもらう自由回答法を採用した。衣服については、 着数を区分し、選択項目から選んでもらうプリコード回答法を採用 した。表 3 の物品内容については、事前に数名の高齢者および紹介 業者に対寸るヒアリングを参考に抽出した。なお、本研究では高龄 者向け住宅に持参する物品の量と種類を正確に把握するためには実

\begin{tabular}{|c|c|}
\hline 調査方法 & アンケート調査 \\
\hline 調査内容 &  \\
\hline 調査日 & $\begin{array}{l}\text { 1回目配布（2011/11/16）2回目配布（同年11/30） } \\
\text { *アンケート回収日（同年12/13、2012/1/15） }\end{array}$ \\
\hline 配布拠点 & $\begin{array}{l}\cdot 1 \text { 回目/紹介業者 K (大阪20部, 東京20部) } \\
\text { •2回目/紹介業者 K (大阪80部, 東京60部)、 } \\
\text { 運営会社 F (20部) }\end{array}$ \\
\hline 回収率 & 回収48部／総配布数200部 (回収率24\%) \\
\hline \multicolumn{2}{|c|}{ 表2 回答者属性 } \\
\hline 性別 & 男性10名 (20\%) 女性38名 (80\%) \\
\hline 年齢構成 & $\begin{array}{l}\text { 50歳未満 (2名, 4\%) 50歳代 (6名, } 13 \% \text { ) 60歳代 (17名, 35\%) } \\
70 \text { 歳代 (13名, } 27 \% \text { ) 80歳代 (9名, } 19 \%) \text { 不明 (1名, } 2 \%)\end{array}$ \\
\hline 世帯構成 & $\begin{array}{l}\text { 単身世帯(26名, } 54 \%) \quad \text { 夫婦のみ世帯(14名, } 29 \%) \\
\text { 子供世帯と同居(1名, } 2 \%) \quad \text { その他 }(7 \text { 名, } 15 \%)\end{array}$ \\
\hline $\begin{array}{c}\text { 自宅 } \\
\text { 所有形態 }\end{array}$ & 持家 (34名, 71\%) 借家(14名, 29\%) \\
\hline $\begin{array}{c}\text { 自宅 } \\
\text { 住居形態 }\end{array}$ & $\begin{array}{l}\text { 戸建住宅 (25名, } 53 \%) \text { マンンション・アパート (17名, } 35 \%) \\
\text { 公営住宅 }(5 \text { 名, } 10 \%) \text { 高齢者住宅 (1名, } 2 \%)\end{array}$ \\
\hline $\begin{array}{l}\text { 自宅の } \\
\text { 間取り }\end{array}$ & $\begin{array}{l}\text { 1LDK (3名, 6\%) 2LDK (7名, 15\%) 3LDK (10名, 21\%) } \\
4 \operatorname{LDDK}(15 \text { 名, 31\%) 5LDK (7名, 15\%) 6LDK (3名, 6\%) } \\
\text { 1DK (2名, 4\%) 2DK (1名, 2\%) }\end{array}$ \\
\hline
\end{tabular}


際に住み替えることを強く意識することが重要であるとし、住み替 えの意識付けのきっかけとして現自宅における物品の保有量につい て記述してもらった上で希望する持参量について回答してもらった。

\section{2-2. 調査対象者の基本属性（表 2）}

表 2 より男女比は、8 割が女性、2 割が男性であった。平均年齢は 69 歳（最高年齢 86 歳、最低年齢 33 歳 ${ }^{\text {注 }}$ 15) であり、60 代、70 代、 80 代の順に多かった。世帯構成は、単身世帯が過半数を越えており、 次いで夫婦のみ世帯となった。これらの両者を合わせた高齢者のみ 世帯の割合は $82 \%$ であった。自宅の所有形態の割合は、持家が $71 \%$ 、 借家が $29 \%$ であった。住居形態は戸建住宅が $53 \%$ と最も多く、続い てマンション・アパートが $35 \%$ と続いていた。住居形態と持ち家率 との関係では、戸建住宅の約 9 割、マンション・アパートの約 6 割 が持家であった。間取りは、4LDK が 31\%と最も多く、続いて 3LDK が $21 \%$ と多かった。2LDK から 5LDK までの合計が全体の $82 \%$ となった。 また、単身者向けの賃貸住宅（1DK、1LDK、2DK）と高齢者向け住宅や ケアハウスからの転居者が合計 6 名（全て単身世帯）いた。

\section{3. 結果}

本章では生活行為別に物品を分類し、高齢者向け住宅に求められ る住戸空間の特質を明らかにする。建築設計資料集成 $[\text { 物品 }]^{19)}$ では 生活行為別に物品を分類しており、本研究では建築設計資料集成を 参考に表 4 のように分類した。生活行為は大きく「生活」、趣味」「教 育・情報」の 3 つに分類し、「生活」についてはさらに細かく「飲食・ 調理」、「更衣・装身・整容」、「休䕀・就寝」、「生活管理」、「宗教」の 5 つに分類した。なお、建築設計資料集成 [物品] では、扇風機、ス トーブと植物は建築物としての「設備・造園」に分類されているが、 本研究では住空間での生活行為に着目しているため扇風機、ストー ブは「生活管理」とし、植物は「趣味」とした。また、イスは「休㮩・ 就寝」に分類されているが、高齢者向け住宅への住み替えに際しては、 「飲食・調理」に分類されるテーブルとセットで考慮されることが多 いと想定されるため「飲食・調理」に分類した。

\section{3-1. 生活に関する物品の保有量と希望持参量}

\section{(1)飲食・調理（図 1、図 2)}

図 1 は飲食・調理に関する家具・家電製品の保有量と希望持参量 （以下、持参量と略す）の平均值である。家具の平均保有量をみると、 イスは 4.6 脚であったが、平均持参量は 1.6 脚に減少していた。テー ブル (4 人以上) も平均保有量は 1.0 脚であったが、平均持参量は 0.3 脚に減少していた。一方、テーブル (2人) の平均保有量は 0.3 脚であっ たが、平均持参量は 0.5 脚に増加していた。

家電製品では、冷蔵庫、炊飯器、電子レンジ、オーブントースター、 ポットの平均保有量は、いずれも $0.8 \sim 1.1$ 個と同程度であった。平 均持参量はオーブントースターの 0.6 個以外は全て $0.8 \sim 1.0$ 個とな り、冷蔵庫については全員が 1 台以上持参すると回答していた。こ のように家電製品については保有量と持参量の差が見られなかった。

次に図 2 は飲食・調理のモノの保有量と持参量の平均值である。食 器類の平均保有量についてみると椀類や皿類は 11 枚以上、鉢類は 6 枚以上、コップ類は自分用コップが 4.8 個、客用コップが 15.9 個と なった。いずれも保有量の個人差が大きく、最も多い人で小皿の保 有量が 60 枚となっていた。持参量については、碗類や皿類は 1.8 枚 - 3.9 枚、鉢類は 1.3 枚 -3.6 枚、コップ類は自分用が 2.6 個、客用

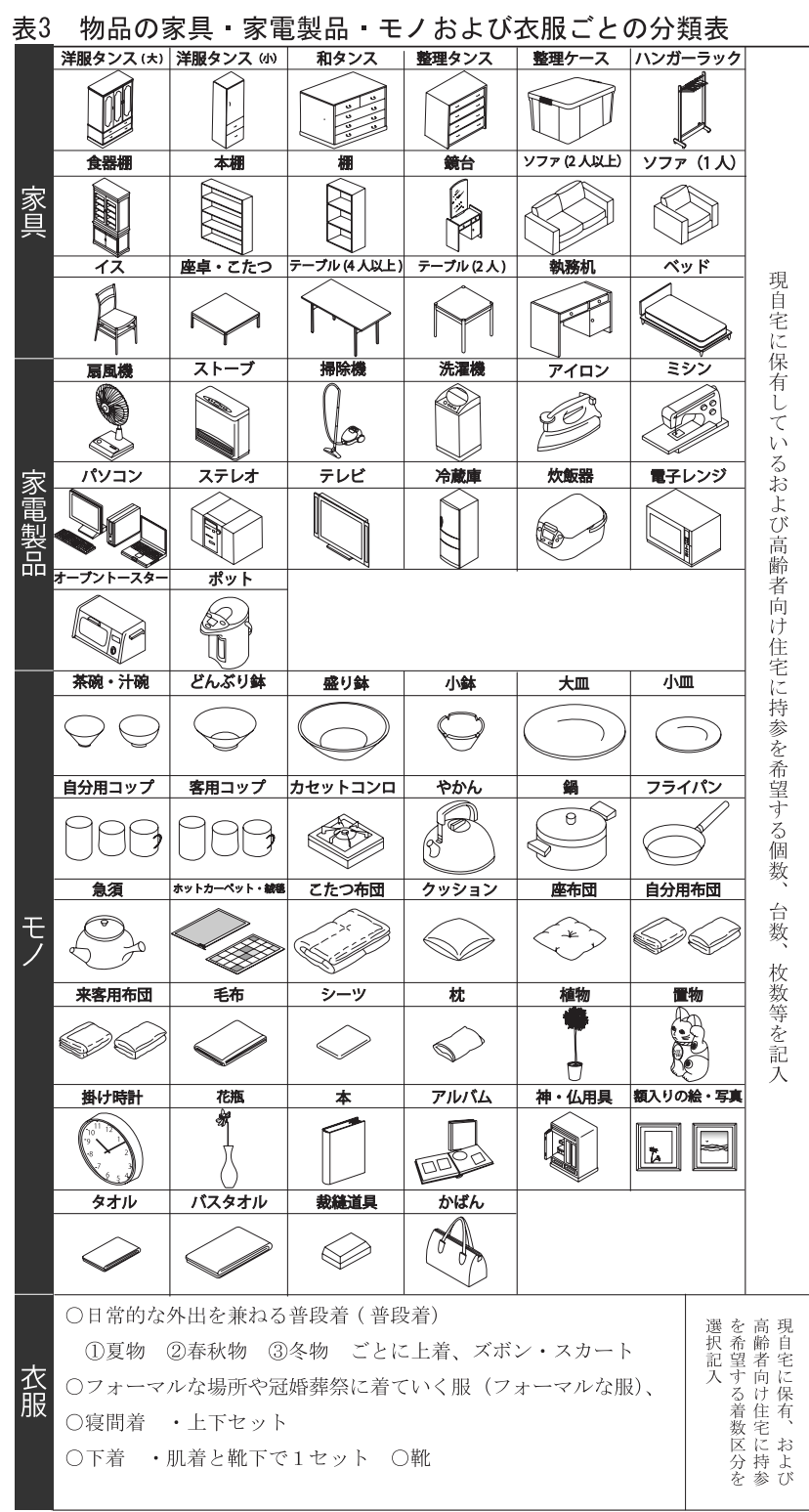

\section{表4 生活行為による物品分類表}

\begin{tabular}{|c|c|c|c|}
\hline & 家具 & 家電製品 & モノ \\
\hline $\begin{array}{l}\text { 飲 } \\
\text { 食 } \\
\text { 調 } \\
\text { 理 }\end{array}$ & $\begin{array}{l}\text { ○食器棚 } \\
\text { ○テーブル人以上) } \\
\text { ○テーブル (2人) } \\
\text { ○イ }\end{array}$ & \begin{tabular}{|l|} 
冷蔵庫○炊飯器 \\
電子レンジ \\
○オープントースター \\
○ポット
\end{tabular} & 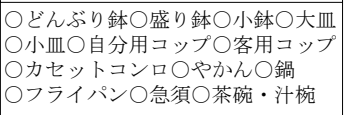 \\
\hline $\begin{array}{l}\text { 更 } \\
\text { 衣 } \\
\text { 装 } \\
\text { 身 } \\
\text { 掣 } \\
\text { 慗 } \\
\text { 容 }\end{array}$ & $\begin{array}{l}\text { ○洋服タンス(大) } \\
\text { ○洋服タンス (小) } \\
\text { ○和タンス } \\
\text { ○整理タンス } \\
\text { ○整理クース } \\
\text { ○六ガーラック } \\
\text { ○鏡台 }\end{array}$ & & 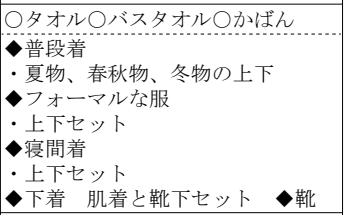 \\
\hline \begin{tabular}{|l} 
休 \\
彭 \\
就 \\
寝
\end{tabular} & $\begin{array}{l}\text { ○ソファ (2人以上) } \\
\text { ○ソファ (1人) } \\
\text { ○座卓・こたつ } \\
\text { ○ベッド }\end{array}$ & & $\begin{array}{l}\text { ○ホットカーペット・䋐毯 } \\
\text { ○こたつ布団○クッション座布団 } \\
\text { ○自分用布団○客用布団○毛布 } \\
\text { ○シーツ○枕 }\end{array}$ \\
\hline $\begin{array}{l}\text { 生 } \\
\text { 活 } \\
\text { 管 } \\
\text { 理 }\end{array}$ & & 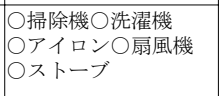 & ○アルバム○掛け時計 \\
\hline \begin{tabular}{|l} 
宗 \\
教
\end{tabular} & & & ○神・仏具 \\
\hline $\begin{array}{l}\text { 趣 } \\
\text { 味 }\end{array}$ & & ○ミシン & $\begin{array}{l}\text { ○置物 } \bigcirc \text { 花瓶○額入りの絵・写真 } \\
\bigcirc \text { 縫道具 } \bigcirc \text { 植物 }\end{array}$ \\
\hline $\begin{array}{l}\text { 㝏教 } \\
\text { 情育 } \\
\text { 報 }\end{array}$ & \begin{tabular}{|l} 
○本棚 \\
$\bigcirc$ 棚 \\
執務机
\end{tabular} & $\begin{array}{l}\text { ○パソコン } \\
\text { ○ステレオ } \\
\text { ○テレビ }\end{array}$ & O本 \\
\hline
\end{tabular}


コップが 2.9 個となった。モノの持参量は大幅に減少しているものの、 小鉢、小皿、客用コップの標準偏差は 5.7 から 6.9 となっており、8 から 10 個程度の持参を希望する人も見られた。調理器具類の平均保 有量についてみるとカセットコンロは 0.7 台となり、保有していな かった人も多かった。やかんは 1.4 個、フライパンは 2.1 枚、急須は 2.9 客となった。概㸚個人差は小さかったが鍋は 5.5 個となり個人差 が大きかった。平均持参量についてみると、カセットコンロは 0.3 台、 やかんは 0.8 個、鍋は 2.0 個、フライパンは 1.2 枚、急須は 1.2 客と なり、約半数程度に減少しており、個人差もほとんど見られなくなっ ていた。

\section{(2)更衣・装身・整容（図 3- 図 9)}

図 3 から図 7 は、衣服の保有量と持参量の着数区分別割合である。 衣服については普段着とフォーマルな服、寝間着、下着、靴の 5 つに 分けた。さらに普段着については冬物、春秋物、夏物ごとに上着とズ ボン・スカートの 2 つに分類した。なお、各季節ごとの上着にはトレー ナー、セーター、シャツ、ワイシャツ、ポロシャツなどを含み、フォー マルな服には礼服の他に着物が含まれることをアンケート中に記載 した。

図 3 は、普段着の保有量と持参量の着数区分別割合である。上着 の保有量は、 5 着以下と 6 着〜 10 着未満（以降、10 着未満と略す） の合計が冬物で $53 \%$ 、春秋物で $65 \%$ 、夏物で $44 \%$ となった。ズボ ン・スカートの保有量は、10 着未満の合計が冬物で $57 \%$ 、春秋物で $66 \%$ 、夏物で $57 \%$ となった。上着の持参量についてみると 10 着未 満の合計が冬物で $85 \%$ 、春秋物で $89 \%$ 、夏物で $74 \%$ となった。ズ ボン・スカートの持参量では 10 着未満の合計が冬物で $93 \%$ 、春秋 物で $94 \%$ 、夏物で $83 \%$ となった。保有量と持参量を比較すると上着 では 10 着未満の割合が冬物で 1.6 倍、春秋物で 1.3 倍、夏物で 1.7 倍に増加していた。さらにズボン・スカートでは 10 着未満の割合が 冬物が 1.6 倍、春秋物が 1.4 倍、夏物が 1.5 倍に増加していた。こ のように上着、ズボン・スカート共に持参量では、10 着未満の割合

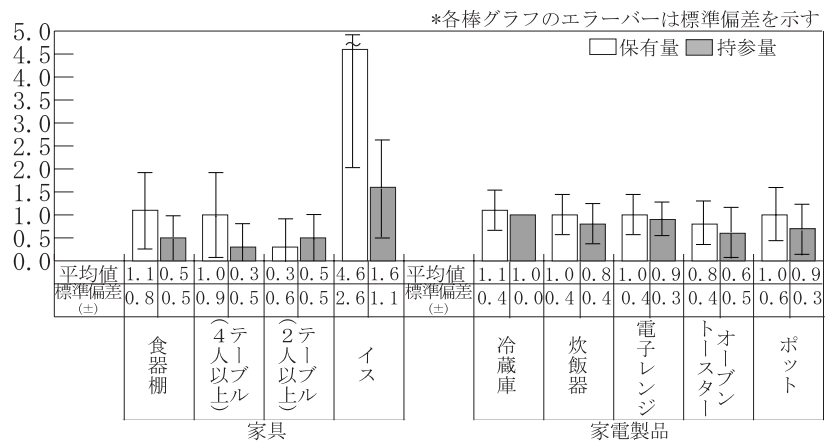

図1 飲食・調理（家具・家電製品）の保有量と持参量

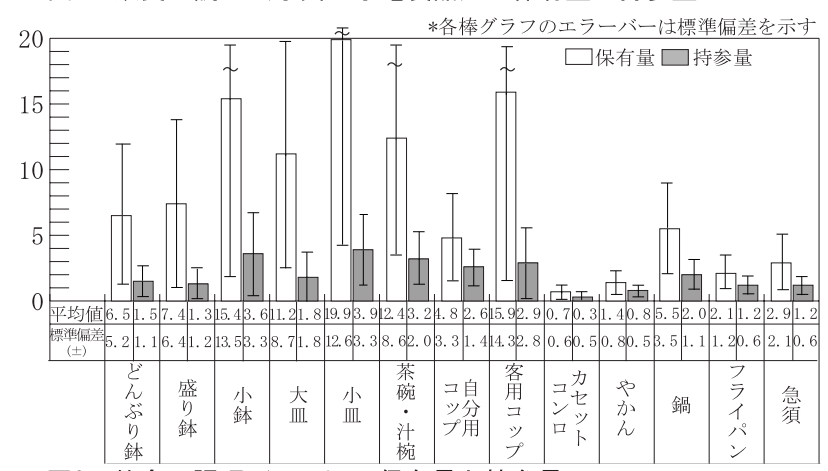

図2 飲食・調理（モノ）の保有量と持参量

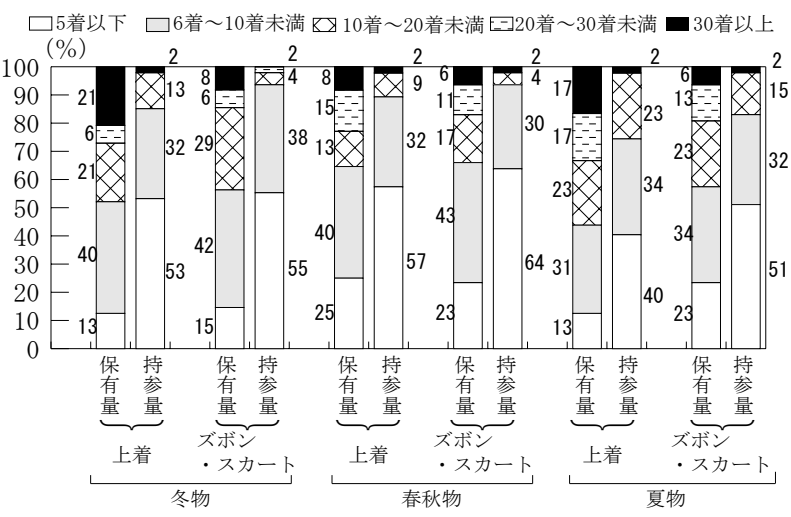

図3更衣・装身・整容（衣服）の普段着の保有量と持参量

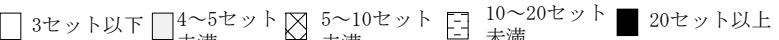

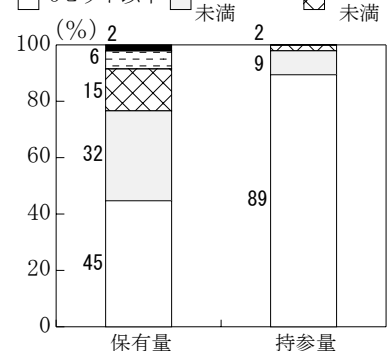

図4 更衣・装身・整容（衣服） のフォーマルな服の保有量と持参量

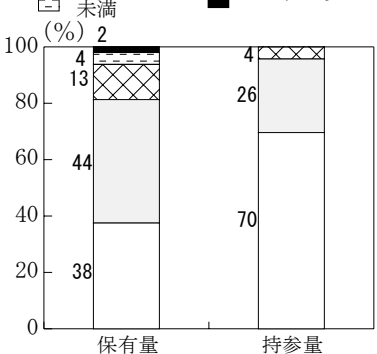

図5 更衣・装身・整容（衣服）

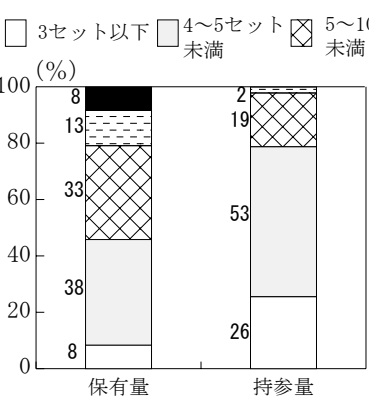

図6 更衣・装身・整容（衣服） の下着の保有量と持参量

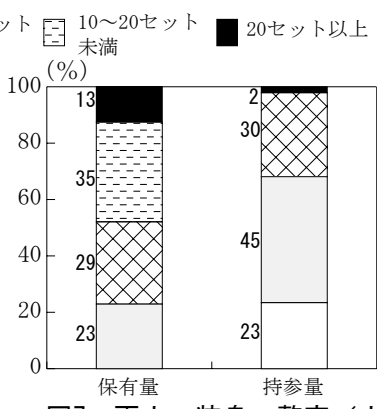

図7更衣・装身・整容（衣服） の靴の保有量と持参量

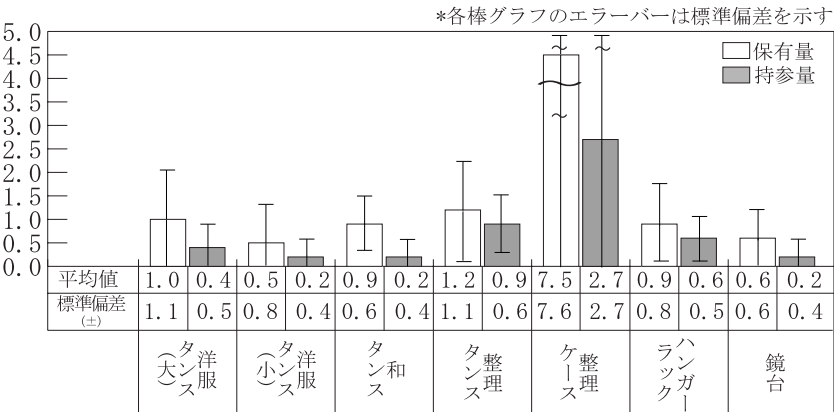

図8 更衣・装着・整容 (家具) の保有量と持参量

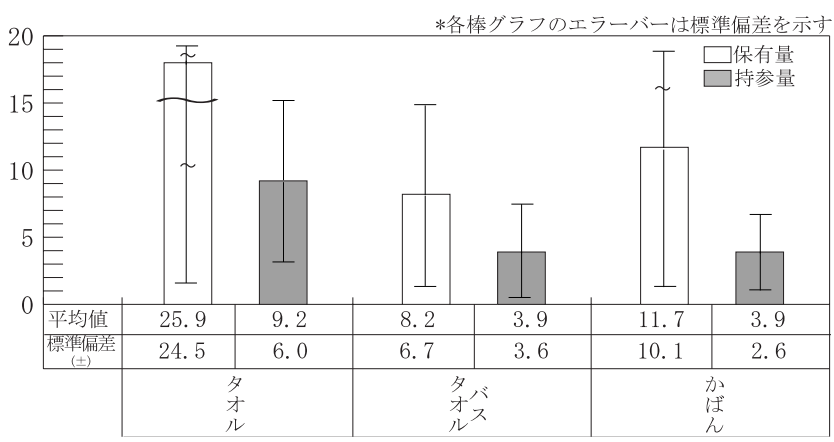

図9更衣・装着・整容（モノ）の保有量と持参量 
が持参量で増加していた。

図 4 は、フォーマルな服の保有量と持参量の着数区分別割合であ る。保有量をみると 3 セット以下が $45 \%$ 、4 5 セット未満が $32 \%$ 、 5 ～ 10 セット未満が $15 \%$ 、10 20 セット未満と 20 セット以上の 合計が $8 \%$ となった。持参量では 3 セット以下が $89 \%$ となり、 4 セッ 卜以上の持参量は極めて少なくなった。

図 5 は寝間着の保有量と持参量の着数区分別割合である。保有量 をみると、3 セット以下と 4 〜 5 セット未満 ( 以降、 5 セット未満と 略す) の合計割合が $82 \%$ となった。持参量は 5 セット未満の合計が $96 \%$ となり、大半が 5 セット未満となっていた。

図 6 は下着の保有量と持参量の着数区分別割合である。保有量を みると、最も高いのは 4 5 セット未満で $38 \%$ 、次に高いのは 5 〜 10 セット未満で $33 \%$ となっていた。最も低いのは 3 セット以下で $8 \%$ であった。持参量をみると、最も高いのは 4 〜 5 セット未満で $53 \%$ 、次に高いのは 3 セット以下の $26 \%$ となり、3 セット以下が増 加していた。

図 7 は靴の保有量と持参量の着数区分別割合である。保有量をみ ると、最も高いのは 10 〜 20 セット未満で $35 \%$ であり、最も低いの は 3 セット以下で $0 \%$ でった。持参量をみると、最も高いのは 4 〜 5 セット未満で $45 \%$ となり、下着と同様に 3 セット以下が $23 \%$ と なり、増加していた。

図 8 は更衣・装身・整容に関寸る家具の保有量と持参量の平均値 である。家具の平均保有量をみると、洋服タンス (大)、整理タンス、 整理ケースは 1.0 台以上であった。洋服タンス (小)、和タンス、八 ンガーラック、鏡台は 0.5 台〜 0.9 台と 1.0 台未満であり、保有して いなかった人も多かった。平均持参量をみると、洋服タンス (大)、 洋服タンス (小)、和タンス、鏡台は 0.5 台未満となり大型家具は持 参されない傾向があった。整理ケースの持参量は 2.7 個となり、収納 家具の持参量の中で平均值、最大值が最も高くなっていた。

図 9 は更衣・装身・整容に関寸るモノの保有量と持参量の平均値 である。保有量をみるとタオルは 25.9 枚、かばんは 11.7 個といずれ も多く、標準偏差もタオルは24.5、かばんは 10.1 となり、共に個人 差が大きかった。持参量についてみると、タオルは 9.2 枚、かばんは 3.9 個と大きく減少していたが個人差は大きいままであった。

\section{(3)休䕀・就寝（図 10、図 11）}

図 10 は休悡・就寝に関する家具の保有量と持参量の平均值であり、 図 11 は休唕・就寝に関寸るモノの保有量と持参量の平均值である。 図 10 から家具の平均保有量をみると、ソファ類は 1.0 脚未満、ベッ ドは 1.0 台となった。座卓・こたつの平均保有量は 1.0 台であったが、 自宅の部屋数の多い人の中には 5 台保有していた人もいた。平均持 参量をみるとソファ類は 0.3 脚以下となり持ち込まれない傾向にある が、ベッドは 0.9 台となり保有量との差も小さく大半が持参を希望し ていた。座卓・こたつは 0.5 台となり持参量が減少しているが、ソファ よりも持参量が多くなっていた。

図 11 からモノの平均保有量をみると、こたつ布団は 0.5 枚、ホッ トカーペット・絨毯は 1.3 枚であった。クッションは 2.9 個、座布団 は 6.3 枚となった。両者ともに個人差が大きく、12 枚保有している 人もいた。布団類は、自分用は 1.6 枚、来客用は 2.1 枚となり来客用 を多く保有していた。毛布、シーツや枕等のリネン類は 3.0 枚以上と なり個人差が大きかった。平均持参量をみると、こたつ布団と来客
用布団は 0.3 枚となり持参しない傾向となった。ホットカーペット・ 絨毯は 0.7 枚となり持参を希望する人も多かった。クッションは 1.1 個、座布団は 1.5 枚と大幅に減少し、ほぼ 1 人から 2 人を想定した数 となっていた。布団類は自分用が 1.2 枚と平均保有量との差がなかっ たが、来客用は 0.3 枚となり大幅に減少した。毛布は 1.7 枚、シーツ は 3.3 枚、枕は 1.3 枚となり保有量から半数以下になっていた。

\section{(4)生活管理（図 12、図 13）}

図 12 は生活管理に関する家電製品の保有量と持参量の平均値であ り、図 13 は生活管理に関するモノの保有量と持参量の平均值である。 図 12 から家電製品の平均保有量をみると、洗濯機は 1.0 台、掃除機 は1.4 台、扇風機とストーブは 1.7 台となり、掃除機、扇風機とストー ブは個人差が大きかった。平均持参量をみると、洗濯機が 0.9 台、掃 除機と扇風機が 0.9 台、ストーブが 0.7 台となり、これらの物品はい ずれも 1 台は持参される傾向にあった。

図 13 からモノの平均保有量をみると、アルバムは 15 冊と多く個人 差が大きかった。掛け時計は 2.3 台となった。平均持参量をみると、 アルバムは 7 冊と半数以下になるが、個人差が大きく最も多く持参 を希望する人で 100 冊となった。掛け時計は 0.8 台となった。

\section{(5)宗教（図 14）}

図 14 は宗教に関するモノの保有量と持参量の平均值である。平均 保有量をみると、神・仏用具は 1.0 基でありモノの中ではばらつきが 小さかった。平均持参量をみると、神・仏用具は 0.7 基となり、神・ 仏用具を保有している場合には持参される傾向が強かった。

\section{3-2. 趣味に関する物品の保有量と希望持参量（図 15、図 16）}

図 15 は趣味に関寸る家電製品の保有量と持参量の平均値であり、 図 16 は趣味に関するモノの保有量と持参量の平均值である。図 15 から家電製品の平均保有量をみると、ミシンは 0.6 台であり、保有 していない人もいた。平均持参量をみるとミシンは 0.2 台となり持 参されない傾向にあった。モノの平均保有量をみると、置物、花瓶、 額入りの絵・写真、植物は 6.0 個以上と多く、個人差も大きかった。 平均持参量をみると、置物、花瓶、額入りの絵・写真、植物は 2.0 個 未満となり数は大きく減少するが、数個は持参される傾向にあった。

3-3. 教育・情報に関する物品の保有量と希望持参量（図 15、図 16)

図 15 は教育・情報に関寸る家具、家電製品の保有量と持参量の平 均值であり、図 16 は教育・情報に関するモノの保有量と持参量の平 均值である。

図 15 から家具の平均保有量をみると、執務机は 1.0 台、本棚は 1.7 台、棚は 1.4 台となり、1〜3 台保有していた人が多かった。家電製 品ではパソコンが 1.1 台、ステレオが 0.7 台、テレビが 1.7 台であっ た。平均持参量をみると、本棚と棚は 0.6 台、執務机は 0.3 台とな り持参を希望しない人が多かった。パソコンは 0.6 台、ステレオは 0.5 台となり持参を希望しない人もいたが、テレビは 1.2 台であり、ほ ぼ全員が持参すると回答していた。

図 16 からモノの平均保有量をみると、本は 165.7 冊と数が多く個 人差も大きかった。保有量の最小值は 4 冊であったが最大值は 1,170 冊であった。平均持参量をみると、本は 29.1 冊と大幅に減少してい るが、個人差が大きく最大値は 200 冊となった。

\section{4. 考察}

\section{4-1. 生活に関する物品}




\section{(1)飲食・調理}

飲食・調理に関連する物品についてまとめると、テーブルの持参 量については 4 人掛け以上が減少し、2 人掛けが増加しており、核家 族用を想定したテーブルから 2 人用・単身用テーブルへの規模の縮 小が想定されていた。イスについては保有量は 4.6 脚となるものの 持参量は 1.6 脚となり、自分用と来客用のイスを想定する人が多かっ た。食器類についてみると保有量は個人差が大きく、かつ、多数の モノを保有している人が多かった。食器類は実用的な用途だけでは なく、嗜好品や贈答品として収集される場合も多く、付加価值的な 意味を持つものも多い。その一方で、持参量の平均は最大でも 3.9 個となり大幅に減少していた。自分用だけではなく客用コップを希 望するなど他者を迎える最低限のモノの持ち込みが想定されている ものの、付加価值的な要素は少なくなっていた。調理器具については、 フライパン、鍋などは複数個を保有しており異なるサイズの道具を持 合せていると考えられるが、持参量はいずれも 1 個となり、種類の 違いがなくなり料理の選択肢が少なくなると想定される。家電製品 については、保有量と持参量ともに個人差が小さく、個数の減少も 見られなかった。また単身者向けの賃貸住宅（1DK、1LDK、2DK）と他 の高齢者向け住宅に居住していた 6 名についてみると、電子レンジ は全員が持ち込みを希望したため持参量が保有量より微増していた。 このように、電子レンジは高齢者向け住宅に住み替える際に最低限 必須の物品として考えられる。

\section{(2)更衣・装身・整容}

更衣・装身・整容に関連する物品についてまとめると、普段着、 フォーマルな服、寝間着、下着、靴の全てが大幅に減少していた。
普段着では、上着よりもズボン・スカートの持参量は少なかった。 フォーマルな服では、持参量で 3 セット以下となる人が大半を占め、 靴では 3 セット以下の人が $23 \%$ を超えた。衣服や靴については 10 着以上保有していた人が半数以上となり、イベントの種類に応じた 衣服の選択や、衣服に合わせた靴の選択を行っていたと考えられる が、転居後は組み合わせが数パターンしかなくなり、選択肢が少な くなっていた。着装行動は、「日常生活を送る上で、最も基本的な行 動」(田中ら ${ }^{20)}$ ) や「社会参加と生活の主体性（目的）とに深い関わ りをもつもの」(上野 $\left.{ }^{21)}\right)$ とされることから、着衣数の減少が自律的 な行動の低下や外出行動の減少につながらないかが危惧される。衣 服を収納する家具については、大型のタンスや整理タンスが保有され ているが、持参量については大型のタンスは処分される傾向にあり、 整理タンスのみが持ち込まれる傾向にあった。また、整理ケースに ついては、2.7 個の持参量があった。整理ケースについては、そのま ま設置されることも多いが、クローゼットなど収納設備内に設置さ れることも多く、収納設備を設ける方が美観上も好ましいことから、 整理ケースの個数を踏まえた収納設備の計画が重要であると考えら れる。

\section{(3)休憩・就寝}

休㮃・就寝に関連する物品については、ベッドについてはそのまま 持参する人が多く、ベッドによる就寝形態が多くなると考えられる。 単身者向けの賃貸住宅に居住している人の中には現在、ベッドを保 有していない人もいたが、全員がベッドの持ち込みを希望しており、 就寝形態としてはベッドが多くなると考えられる。休䕀用の家具とし ては、ソファ類は持参されなかったが、座卓・こたつは 1 台の持参を

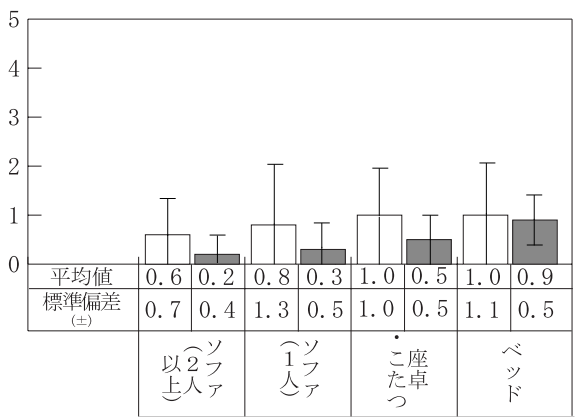

図10 休敗・就寝 (家具)の保有量と持参量

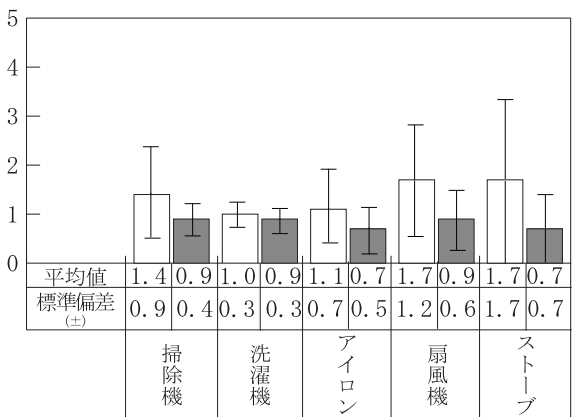

図12 生活管理(家電製品)の保有量と持参量

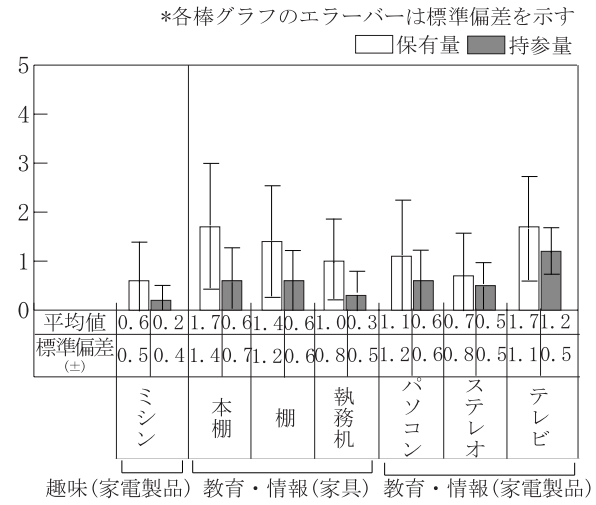

図15趣味(家電製品)および教育・情報 (家具・家電製品)の保有量と持参量

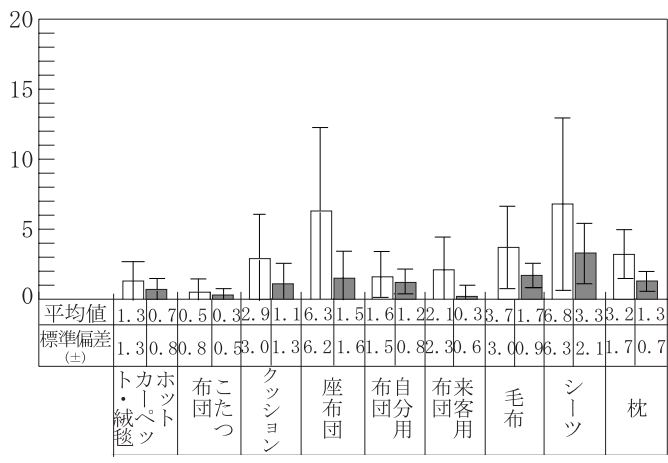

図11 休䕀 - 就寝 (モノ)の保有量と持参量

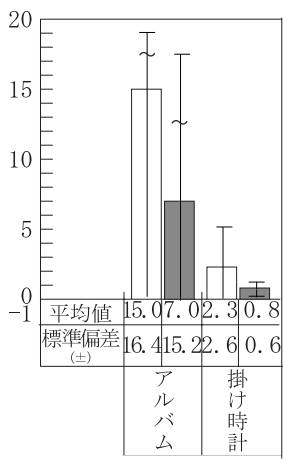

図13 生活管理(モノ) の保有量と持参量

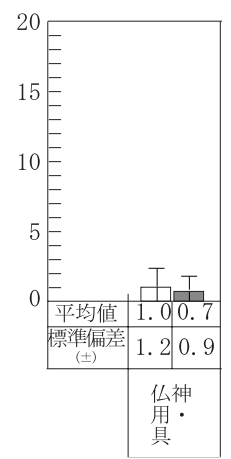

図14 宗教(モノ) の保有量と持参量
*各棒グラフのエラーバーは標淮偏差を示寸

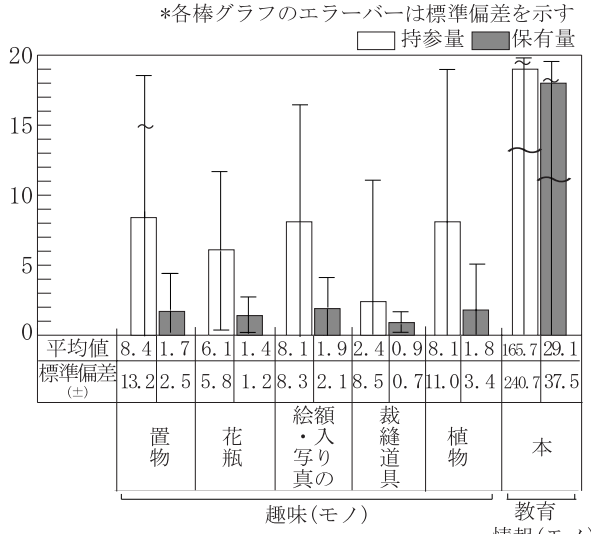

図16 趣味(モノ)および教育・情報(モノ) の保有量と持参量 
希望していた人が多かった。ベッドやテーブル・イスなどイス座の生 活様式に対応した家具が持ち込まれる一方で、休輴スペースとしては こたつなどのユカ座の生活様式が求められており、住戸にはユカ座 とイス座に対応した 2 以上のスペースが必要であると考えられる。

モノの持参量については、座卓・こたつと組み合わせて利用する クッションや座布団の数が大幅に減少していたが、来客用を想定して $2 \sim 3$ 個の持参を希望していた人も多かった。ただし、来客用布団に ついては、持参を希望されず、来客の宿泊までは想定されていなかっ た。

\section{(4)生活管理}

家電製品の持参量については、扇風機、ストーブ等の季節家電や掃 除機、アイロンは 1 つ以上の持参が希望されていた。多くの高齢者向 け住宅においてエアコンの既設が想定されるが、これまで親しんでき た方法による室温の制御を希望する人が多い。また、掃除機やアイロ ンの持ち込みが希望されており、自分で環境をコントロール（整える） しようとする意欲が高いと考えられる。このように扇風機やストー ブなど季節ごとに出し入れするものを収納するスペースを住戸内も しくは共用部のトランクルームなどに設ける必要があると考える。

\section{(5)宗教}

宗教の持参量については、神・仏用具は 1 基以上の持参が希望さ れていた。保有量の平均值との差は小さく、そして他のモノと比較 すると個人差も小さいことから高齢者向け住宅の住戸内には神・仏 用具を配置できる祈りのためのスペースの確保が必要となる。

\section{4-2. 趣味に関する物品}

趣味に関連する保有量、持参量はともに個人差が大きかったが、置 物、花瓶、額入りの絵・写真、植物はいずれも 1 個以上は持参される 傾向にあった。物品を飾る行為はモノの付加価值と結び付くことか ら、これらのモノを飾ることを想定した住戸内の設えが必要と考え られる。また、これらの物品については、運営会社と協議の上で廊 下や食堂などの共用空間に飾るということも可能である。共用部に ついても「飾る」という行為が誘発される設えに留意す心゙きと考える。

\section{4-3. 教育・情報に関する物品}

家具や家電製品についてみると、テレビはそのまま持参すること を希望しており、パソコンについては持参する人としない人に分か れた。モノでは、本の持参量が多く平均して 29.1 冊となった。アル バムや本は個人の記憶やアイデンティティの確認とも密接な関係を 持つ。書籍については個人差が大きく大量の持ち込みを希望する人 もいたことから、住戸内だけではなく共用部に図書コーナーを設け るなど、共用空間内で管理することについても検討する必要がある と考えられる。

\section{5. 結論}

本研究では高齢者向け住宅への入居希望者に対するアンケート調 查から現在の物品の保有量と、高齢者向け住宅への希望持参量につ いて把握した。以下に保有量と持参量を比較した結果から考察され る物品の重要性と住戸計画上、配慮すべき点について列挙する。

(1) キッチンまわり: 食器類の持参量の平均は最大でも 3.9 個となり 保有量の平均から大幅に減少していた。食器類は実用的な用途に限 定されて持参されると考えられる。ただし、客用コップの持参を希 望するなど他者を迎える最低限の物品の持ち込みは想定されていた。
調理器具は、種類ごとに 1 個 1 サイズを持参する程度に減少していた。 調理家電は、自宅で保有していた個数をそのまま持参していた。キッ チン・台所については、湯沸し程度の利用を想定した小規模なキッ チンではなく、最低限ではあるが自立した生活が営める食器や家電 製品、調理器具を収納できる調理スペースの計画が必要となる。

(2) 食堂 : 単身生活であっても 2 人掛けのテーブルと複数のイスの持 参を希望し、日中の住戸内への来客を想定していた。これより、食 事だけではなく来客を見越した食堂の計画が必要となる。

（3）居間・寝室 : ベッドは自宅にある 1 台をそのまま持参しており、 ベッドによる就寝形式が重視されていた。ソファ類は持参されない が、座卓・こたつはクッションや座布団とセットで持参され、ユカ 座を希望する人もいた。居間・寝室については、ベッドを中心とし たイス座生活だけではなく、ユカ座を想定したスペースの確保も必 要である。

（4）収納：大型タンス類は持参されない傾向にあるが、整理ケース は半数以下に大幅に減少させながらも 2.7 個の持参が想定されてい た。タンス類の持ち込みが減少すると想定されることから、整理ケー スを収納するクローゼットが必要となると考えられる。また、季節 物の家電の持参も想定されており、これらを保管するための収納ス ペースとして住戸内または共用部に設置された個人用のトランク ルームが必要となる。

（5）展示：本やアルバム、趣味に関連する小物などの物品は大きく 量が減少するものの、複数の物品を持参することが想定されていた。 これらの物品については個人差が大きく、付加価值的な要素を求め る人もいることから、物品を収納・陳列できる棚を設置できるスペー スや貼付・壁掛けできる壁仕様などへの配慮が必要となる。また、 高齢者向け住宅の入居者が全員で観賞できる絵画、置物、植物など の趣味に関する物品や本などは運営会社に寄贈することも考えられ、 共用部に展示スペースを確保することについても検討することが必 要となる。

最後に本研究では、間取りを固定せず希望する物品の抽出を試みた が大幅な物品の減少が見られた。この值には実際に必要ないという側 面と、狭小な高齢者向け住宅には持っていくことができないという自 己判断の双方が重複していると想定される。特に、サ高住については、 住戸面積が最低面積となる $25 \mathrm{~m}^{2}$ 以下の物件の供給が多くを占めてい る現状からも上記傾向が顕著となることが予想される。今後は実際 に持ち込まれた物品についての実態調査を最低面積帯近傍の複数の 住戸にて実施し、調查結果についての確認を行うことが必要と考え られる。

\section{謝辞}

本研究にご協力頂きました各紹介業者、運営会社の皆様に深く感 謝申し上げます。また、本研究に関する調查に協力頂きました徳永 真也氏に深く感謝申し上げます。なお、本調査の一部は徳永真也氏 の卒業論文（近畿大学, 2011 年度）として実施されています。

注

注 1) 日本の総世帯に対する 65 歳以上の高齢者のいる世帯の割合は文献 1 によ ると 2010 年時点で $42.6 \%$ となる。そのうち高齢者の単独世带と夫婦のみ世 帯が占める割合は、文献 2 によると $54.1 \%$ となる。少子高齢化の進行によ 
り高齢者のみ世帯の増加が予想される。

注 2）文献 3 より高齢者のいる主世帯の所有の関係割合は、持ち家が $83.4 \%$ と なり、高齢世帯の持家率は高い。

注 3）文献 4 より虚弱化したときに望む居住形態として、日本の 60 歳以上男女 の $46.2 \%$ が現在のまま自宅に留まりたいと回答している。

注 4）文献 5 より現在のシニア・シルバー世代は、住み替え前の住まいが持ち 家一戸建ての場合は $74.9 \%$ が持ち家一戸建てに、住み替え前が分蚊マンショ ンの場合は $74.3 \%$ が分譲マンションに住み替えている。住み替えの時期別に 見てみると、住み替え前が持ち家一戸建ての場合、11 年以上前は持ち家一戸 建てへの住み替えが $91.0 \%$ を占めていたのに対し、直近 10 年では $39.2 \%$ に まで減少し、代わって分譲マンションへの住み替えが $4.5 \%$ から $35.4 \%$ 、 貢貸住宅等への住み替えは $4.5 \%$ から $25.4 \%$ 一と増加している。住み替え前 の住まいが分譲マンションの場合は、11 年以上前は $5.0 \%$ たった貨貸住宅等 への住み替えが、直近 10 年では $17.8 \%$ と増加している。

注 5）同登録制度の創設が内容に含まれる高齢者住まい法の改正法が平成 22 年 4 月に公布された。文献 6 より登録基準は、床面積を原則 $25 \mathrm{~m}^{2}$ 以上とする 等の住宅に関寸る基準、少なくとも安否確認・生活相談サービスを提供する 等のサービスに対する基準の他、契約内容に対する基準などが設けられてい る。また文献 7 より 2014 年 1 月末現在の登録件数は 4, 303 件、登録総戸数 は138, 444 戸であった。

注 6) 文献 5 より直近 10 年間の持家戸建から分譲マンションや賃貸住宅等の住 替えでは、特に 60 歳代、70 歳以上において床面積の規模の縮小が見られる と報告されている。

注 7) 本研究では物的所有物全般を物品と称し、物品を家具、家電製品、衣服 とそれ以外のモノに分類し、分析を行う。

注 8) 文献 15 よりサービス付き高齢者向け住宅 (N=1, 537) の物件ごとの平均要 介護度として 2 未満の物件が無回答を除くと $57.4 \%$ 占めており、全体の 平均要介護度は 1.81 と報告されている。

注 9) 文献 16 より規模・設備等の各条件に緩和措置があり、共用部分に共同し て利用するためる適切な台所、収納設備または浴室を備えたものであり、居 間、食堂、台所その他の住宅の部分が高齢者が共同して利用するため十分な 面積を有する場合、住戸面積は $18 \mathrm{~m}^{2}$ 以上でよいとされている。

注 10) 全ての設備とは、トイレ、洗面、浴室、キッチン、収納を示す。

注 11）文献 17 の p. 15 グラフ【各設備の有無別の供給状況】

注 12) 本研究における持参量とは高齢者が自宅に保有する多くの物品の中から 再評価し、選別するという主体的な行為を通して得られた持参を希望する物 品の量を表している。物品量については、実際に使われている高齢者向け住 宅での物品量を把握する方法もあるが、これらの值は、建物自体の住戸面積 や平面計画に強く影響を受けることから、本研究では持参量を把握する指標 として、住み替え先を高齢者向け住宅として想定した希望值を採用した。

注 13）紹介業者Kでは多くの高齢者向け住宅や各種の有料老人ホームを紹介し ており、介護関係のセミナーや見学会も定期的に開催していた。また、住宅 運営会社Fにおいても、運営する高齢者向け住宅の見学会を随時開催してい た。そのため、来訪する高齢者は、一般の高齢者と比較すると、高齢者向け 住宅の建物内容やサービス内容の現状を把握している人が多く、アンケート 調査の前提条件以外に、供給の現状を意識した上で回答される影響も少なか らず考えられる。しかし、本研究では高齢期の住み替え前後の物品量の量的 変化の実態を把握することも研究目的としている。よって、現在の自宅から 高齢者向け住宅に住み替える意識が低いことで、住み替え先の高齢者向け住 宅での生活を強く意識せずに回答してしまう可能性を排除することを重視 し、高齢者の中でも住み替え意向の高い人が多い紹介業者や住宅運営会社と 接触している高歯者に限定した調査を実施した。

注 14）文献 17 、文献 18 によるとサ高住の供給の大半は、要介護高齢者を入居 対象とした介護施設の代替機能の役割を担うサ高住であると報告されてい

る。本研究では、早めの住み替えの場としての役割も担える高齢者向け住宅 であることを想起しやすいように、当条件を付与した。

注 15）アンケート回答者の 48 名中、2 名（59 歳、65 歳）は同居する親の代理 として回答していた。また、最低年齢であった 33 歳の 1 名は、将来的に高 齢者向け住宅への入居を検討したいとの意向があった。その他の 50 歳代お よび 50 歳未満の 6 名についても、高齢期とは言い難い年齢ではあったが、 高齢者向け住宅への入居意向があることをアンケート調查から確認できたた め、本研究では上記 9 名の回答を有効回答とした。

\section{参考文献}

1) 内閣府 : 平成 25 年版高齢社会白書

2) 国立社会保障・人口問題研究所 : 日本の将来推計人口 (平成 24 年 1 月推計)

3) 総務省 : 平成 20 年住宅・土地統計調査, 2011.03
4) 内閣府 : 平成 25 年版高齢社会白書 (全体版)（PDF形式）

5）一般社団法人不動産流通経営協会 : 高需期における住替え意向に関寸る把握調査, 2012. 06

6) サービス付き高齢者向け住宅法令通知ハンドブック 2012 年度版, 株式会社厚生行政 出版会, 2012

7) 月間シニアビジネスマーケット 3 月号, 総合ユニコム株式会社, 2014.03

8) 池内裕美, 藤原武弘, 土肥伊都子 : 拡張自己の非自発的喪失 : 大震災による大切な 所有物の喪失調査結果より，社会心理学研究，第 16 巻第 1 号, pp. 27-38, 2000

9）古賀紀江, 高橋鷹志, 外山義, 橘弘志 : 環境移行における「もの」の意味に関寸る 研究，日本建築学会計画系論文集, No. 551, pp. 123-127, 2002. 12

10) Tadashi Toyama: IDENTITY AND MILIEU( (学位論文), 1988

11）大原一興 : 高齢者居住施設におけるパーソナライゼーション 日本建築学会編人間 一環境系のデザイン, 彰国社, 1997

12）橘弘志, 外山義, 高橋鷹志, 古賀紀江 : 個室型特別養護老人ホームにおけ る個室内の個人的領域形成に関寸る研究，日本建築学会計画系論文集， No. 500, pp. 133-138, 1997. 10

13）古賀紀江，横山ゆりか：高歯者居住施設入居者の「もの」環境の経年変化 に関する研究 ADL及び認知症程度と「もの」の量からの分析, 日本建築 学会大会学術講演梗概集, E-1, pp. 159-160, 2009.09

14）小滝一正, 酒井浩次 : 老人の私物とその収納について一特別養護老人ホームの建築 計画に関する研究一, 日本建築学会大会学術講演梗概集計画系, No. 54, pp. 941-942, 1979. 09 15）一般社団法人高齢者住宅推進機構 : サービス付き高齢者向け住宅等の供給動向や地 域の需要を踏まえた事例の分析・整理とその結果に基づく持続性・安定性のある事 業類型（モデル）の提示と普及方策 , 2014.03

16）日経ヘルスケア編集部:サービス付き高齢者向け住宅完全ガイド，日経B P 社,2013.04 17）一般財団法人住宅改良開発公社: サービス付き高齢者向け住宅に関する調査報告 書, 一般財団法人日本不動産研究所, 2013.03

18）高齢者住宅研究所:サ一ビス付き高齢者向け住宅登録の動向 2013. 12. 31 現在, 2014. 01

19）日本建築学会：建築設計資料集成拡張編 [物品 ], 2003.3

20）田中優, 他 5 名 : 高齢者の自律と着装行動に関寸る研究-着装基準重視と関連す る要因の検討一, 日本䋊維製品消費科学会䋊維製品消費科学, Vol. 39, pp. 56-62, 1998. 11

21）上野裕子：高齢者と衣服一高齢者の生活意識と着装行動一, 日本繊維製品消費科学 会繊維製品消費科学, Vol. 39, pp. 29-35, 1998. 11 


\author{
Masayuki YAMADA* , Kentaro YAMAGUCHI ** and Mitsuo TAKADA*** \\ * Graduate Student, Graduate School of Engineering, KYOTO Univ., M. Eng. \\ ** Assoc. Prof., Faculty of Architecture, KINKI Univ., Dr. Eng. \\ *** Prof., Graduate School of Engineering, KYOTO Univ., Dr. Eng.
}

\title{
Introduction
}

Many earlier studies on the personal belongings of elderly people focused on care-needing elderly in nursing homes. However, little was known about the situation in which self-supporting elderly people bring their belongings to a new dwelling.

\section{Purpose of research}

The purpose of this study was to clarify the quantity of personal belongings that soon-to-be residents of serviced housing for the elderly wished to bring with them, in order to obtain fundamental data, particularly with regard to the design of dwelling units in serviced housing. The items considered included furniture, home electronics, clothing, and personal effects.

\section{Research Method}

We used a questionnaire survey to investigate the quantity of personal belongings that elderly people intended to bring with them when they were moving to a private room in a serviced residence. The participants were elderly people visiting the nursing home agency "K", and touring for the first time residences owned by the company "F", which manages serviced housing for the elderly. The number of surveys distributed was 200, and the number collected was 48 , giving a collection rate of $24.0 \%$. The following prerequisites were set. (1) The participants would be living in a single-person room in the serviced residence. (2) They would sell their present home before moving. (3) They should not consider the floor area of the new dwelling unit. (4) Life support services would be provided in the serviced residence, but care services would not. (5) In the serviced residence, there is a common dining room and kitchen, but residents may cook meals other than dinner in their own private room.

\section{Conclusions}

(1) Kitchen: On average, they wished to bring 1.8 platters, 3.9 small plates, 1.5 bowls, 3.6 small bowls and 3.2 rice bowls, which were significantly less than the number they had in their former dwelling. Since they needed tea cups for visitors, the average number that they wished to bring was 2.9. Concerning cookware, they expressed a desire to bring one of every type of item that they owned. In the case of electrical appliances used for cooking, they wished to bring all the items that they possessed to the new dwelling. (2) Dining room: They expressed a preference for a table for two people, together with chairs, for situations when they received visitors. (3) Living room and bedroom: They wished to bring the bed that they currently possessed. They did not intend to bring a sofa, but instead a low table and a "kotatsu" with cushions. (4) Storage: For each type of clothing item, including formal clothes, pajamas, underwear, and shoes, all of which they had a large amount of in their former dwelling, they intended to reduce the number sharply when moving into their new dwelling. Instead of bringing a large chest of drawers, they wished to bring an average of 2.7 storage cases. (5) Personal effects: They intended to choose a small number from the many books, photograph albums and accessories that were in their existing dwelling. 